\title{
Nitric Oxide Induces Heat-shock Protein 70 Expression in Vascular Smooth Muscle Cells Via Activation of Heat Shock Factor 1
}

\author{
Qingbo Xu, ${ }^{*}$ Yanhua Hu, ${ }^{*}$ Roman Kleindienst, ${ }^{\ddagger}$ and Georg Wick \\ *Institute for Biomedical Aging Research, Austrian Academy of Sciences, A-6020 Innsbruck; and ${ }^{\ddagger}$ Clinic for Internal Medicine, University \\ Hospital of Innsbruck, A-6020 Innsbruck, Austria
}

\begin{abstract}
Current data suggest that nitric oxide (NO) is a doubleedged sword that could result in relaxation and/or cytotoxicity of vascular smooth muscle cells (SMCs) via cGMPdependent or -independent signal pathways. Stress or heat shock proteins (hsps) have been shown to be augmented in arterial SMCs during acute hypertension and atherosclerosis, both conditions that are believed to correlate with disturbed NO production. In the present study, we demonstrate that NO generated from sodium nitroprusside (SNP), $\mathrm{S}$-nitroso- $\mathrm{N}$-acetylpenicillamine, and spermine/nitric oxide complex leads to hsp70 induction in cultured SMCs. Western blot analysis demonstrated that hsp70 protein expression peaked between 6 and $12 \mathrm{~h}$ after treatment with SNP, and elevated protein levels were preceded by induction of hsp70 mRNA within $3 \mathrm{~h}$. Induction of hsp70 mRNA was associated with the activation of heat shock transcription factor 1 (HSF1), suggesting that the response was regulated at the transcriptional level. HSF1 activation was completely blocked by hemoglobin, dithiothreitol, and cycloheximide, suggesting that the protein damage and nascent polypeptide formation induced by NO may initiate this activation. Furthermore, SMCs pretreated with heat shock $\left(42^{\circ} \mathrm{C}\right)$ for 30 min were significantly protected from death induced by NO. Thus, we provide evidence that NO induces hsp70 expression in SMCs via HSF1 activation. Induction of hsp70 could be important in protecting SMCs from injury resulting from NO stimulation. (J. Clin. Invest. 1997. 100:1089-1097.) Key words: heat shock proteins - heat shock transcription factor • nitric oxide $\bullet$ smooth muscle cells $\bullet$ arteriosclerosis
\end{abstract}

\section{Introduction}

All organisms respond to detrimental environmental factors by induction of a group of protective proteins termed stress, or heat shock, proteins (hsp). ${ }^{1}$ The hsps are subdivided into multimember families based on the molecular weights of the proteins encoded (the hsp90, hsp70, hsp60, and the small hsp families), of which hsp70 is one of the most extensively studied in mammalian cells. These proteins are highly conserved throughout evolution, and play essential roles as molecular chaperones

Address correspondence to Dr. Qingbo Xu, Institute for Biomedical Aging Research, Austrian Academy of Sciences, Rennweg 10, A-6020 Innsbruck, Austria. Phone: +43-512-583-9190; FAX: +43-512-5839198. E-mail: qingbo.xu@oeaw.ac.at

Received for publication 19 February 1997 and accepted in revised form 16 June 1997.

J. Clin. Invest.

(C) The American Society for Clinical Investigation, Inc. 0021-9738/97/09/1089/09 \$2.00

Volume 100, Number 5, September 1997, 1089-1097

http://www.jci.org under both normal and stressed conditions by facilitating the folding of nascent proteins, resolubilizing protein aggregates that have already formed, and assisting in refolding denatured proteins (for review see references $1-3$ ).

The heat shock response is mainly regulated at the transcriptional level, and is mediated by one or more heat shock transcription factors (HSFs) that interact with a specific regulatory element, the heat shock element (HSE), present in the hsp gene promoters $(4,5)$. HSFs are present constitutively in the cell in a non-DNA binding state, and are activated to a DNA binding form in response to various stresses. The activation process appears to involve HSF oligomerization from a monomeric to a trimeric state, and is associated with its hyperphosphorylation (6-8). Two distinct HSFs have been shown to exist in mammalian species $(9,10)$. Recent studies have suggested that functional differences exist between HSF1 and HSF2, and that the signals that activate one or the other to a DNA-binding state are specific. HSF1 has been shown to be involved in the regulation of hsp expression in response to such inducers as elevated temperature, heavy metals, and amino acid analogues, while HSF2 appears to be involved in hsp expression during hemin-induced differentiation of human erythroleukemia cells (9-11).

In vascular smooth muscle cells (SMCs), hsp induction has been observed under various physiological or pathophysiological conditions, such as hemodynamic changes (12), surgical stress (13), and atherosclerosis (14-16). This induction has been shown to be associated with a protective role in normal and diseased arteries (17), however, the molecular mechanisms regulating this response in SMCs remain unknown.

Nitric oxide (NO) is an unstable but multifunctional molecule that mediates a number of diverse physiological or pathological processes such as smooth muscle relaxation and cytotoxicity $(18,19)$. NO can stimulate the $S$-nitrosylation of numerous proteins to modify these proteins (20), and also binds to the nonheme iron of ribonucleotide reductase to inhibit DNA synthesis (20). In vivo increased production of NO has been observed in response to hemodynamic stress, sepsis shock, and endotoxin (21). In vitro, it has been demonstrated that interleukin 1 (IL-1) and shear stress cause NO induction in vascular cells (21-23). Questions arise as to whether the effects of NO on SMCs evoke increased expression of hsp, and whether hsp are required for NO to play a role in pathophysiological conditions in SMCs. In the present studies, we examined the possibility that NO per se results in hsp70 production in cultured SMCs. We found that the NO-generating compounds sodium nitroprusside (SNP), $S$-nitroso- $N$-acetylpenicillamine (SNAP),

1. Abbreviations used in this paper: GAPDH, glyceraldehyde-3 phosphate dehydrogenase; HSE, heat shock element; HSF, heat shock transcription factor; hsp, heat shock protein; NO, nitric oxide; SMC, smooth muscle cell; SNAP, $S$-nitroso- $N$-acetylpenicillamine; S/NO, spermine/nitric oxide complex; SNP, sodium nitroprusside. 
and spermine/nitric oxide complex (S/NO) that spontaneously release $\mathrm{NO}$ in aqueous medium induce hsp protein production and hsp70 mRNA expression mediated by HSF1 activation.

\section{Methods}

Cell culture and treatment. SMCs were isolated by enzymatic digestion of the aorta from rats according to the procedure of Ross (24), and cultured in medium 199 (GIBCO BRL, Gaithersburg, MD), supplemented with $20 \% \mathrm{FCS}$, penicillin $(100 \mathrm{U} / \mathrm{ml})$, and streptomycin $(100 \mu \mathrm{g} / \mathrm{ml})$. Cells were incubated at $37^{\circ} \mathrm{C}$ in a humidified atmosphere of $95 \%$ air $/ 5 \% \mathrm{CO}_{2}$. The medium was changed every $3 \mathrm{~d}$, and cells were passaged by treatment with $0.05 \%$ trypsin $/ 0.02 \%$ EDTA solution. Experiments were conducted on SMCs (passages 6-15) that had just achieved $90 \%$ confluence. NO-generating compounds SNP, SNAP, and S/NO (Research Biochemicals, Inc., Natick, MA) prepared freshly before use were added to the cultures. EGTA, DTT, and cycloheximide (Sigma Chemical Co., St. Louis, MO) were added to the culture with or without further NO treatment. After incubation for various periods of time at $37^{\circ} \mathrm{C}$, cells were harvested for protein preparation or RNA isolation.

Protein extractions and Western blot analysis. SMCs were incubated with SNP, SNAP, or S/NO at $37^{\circ} \mathrm{C}$ for the indicated times in the figure legends. For heat shock, cells were heated at $42^{\circ} \mathrm{C}$ for $30 \mathrm{~min}$ and then incubated at $37^{\circ} \mathrm{C}$ for up to $8 \mathrm{~h}$. The cells were washed with precold $\left(4^{\circ} \mathrm{C}\right)$ PBS ( $\left.\mathrm{pH} 7.4\right)$ two times, and were then harvested on ice in buffer containing $20 \mathrm{mM}$ Hepes ( $\mathrm{pH} 7.5$ ), $0.4 \mathrm{M} \mathrm{NaCl}, 10 \%$ glycerol, $1.5 \mathrm{mM} \mathrm{MgCl}, 0.2 \mathrm{mM}$ EDTA, $1 \mathrm{mM}$ DTT, $1 \mathrm{mM}$ Pefablock SC (Boehringer Mannheim, Mannheim, Germany) and $1 \mu \mathrm{g} / \mathrm{ml}$ leupeptin. The suspension was incubated on ice for $20 \mathrm{~min}$, vortexing every $5 \mathrm{~min}$. Then, cellular debris was pelleted by centrifugation for $30 \mathrm{~min}$ at 13,000 rpm (Eppendorf centrifuge; Osterode, Germany) at $4^{\circ} \mathrm{C}$. Supernatants were collected, and the protein concentration was measured by the Bio-Rad Assay (Bio-Rad Laboratories, Hercules, CA). Aliquots were frozen in liquid nitrogen, and stored at $-80^{\circ} \mathrm{C}$.

50 or $80 \mu \mathrm{g}$ of total SMC proteins was separated by electrophoresis through a $10 \%$ SDS-polyacrylamide gel, and transferred to an Immobilon-P transfer membrane (Millipore Corp., Bedford, MA). The membranes were processed with a monoclonal antibody to hsp70 (Catalog no. SPA-810; StressGen Biotechnologies Corp., Victoria, British Columbia, Canada [25]) as described (26), which specifically recognizes inducible but not constitutive members of hsp70 family in mammalian cells. For HSF1 analysis, nuclear proteins $(20 \mu \mathrm{g} / \mathrm{lane})$ (for preparation see below) were used. Antibodies against mammalian HSF1 (gifts from Dr. R.I. Morimoto, Northwestern University, Evanston, IL $[9,26])$ were used in a dilution of 1 to 5,000. Specific antibody-antigen complexes were detected using the ECL Western Blot Detection Kit (Amersham Intl., Buckinghamshire, United Kingdom).

RNA isolation and Northern blots. Total RNA was isolated following a standard protocol, as described previously (27). RNA (10 $\mu \mathrm{g} / \mathrm{lane}$ ), was denatured with formaldehyde (Merck, Darmstadt, Germany), electrophoresed in a $1 \%$ agarose gel, and transferred onto a nylon membrane (Zeta Probe; Bio-Rad Laboratories). RNA was UV-cross-linked in a UV Stratalinker (Stratagene Inc., La Jolla, CA). Hybridizations were performed using an $\alpha{ }^{32} \mathrm{P}$-labeled cDNA probe for hsp70 as previously described $(26,28)$, and sequentially for glyceraldehyde-3 phosphate dehydrogenase (GAPDH [29]). Hsp70 cDNA was shown to hybridize with inducible and constitutive forms of mammalian HSP70 $(26,28,30)$. Accuracy of loading and transfer, as well as the integrity of the RNA, was confirmed by quantitative analysis of GAPDH levels on the same blots. Autoradiographs of the blots were obtained in the linear range of detection.

Gel mobility shift assays. For nuclear protein preparation, the procedure used was similar to that described by Schreiber (31) with slight modification. Subconfluent (80-90\%) SMCs were treated with $\mathrm{NO}$ donors at $37^{\circ} \mathrm{C}$ for various periods of time. For heat shock, cells were heated at $42^{\circ} \mathrm{C}$ for $30 \mathrm{~min}$. The cells were washed and harvested with cold TBS ( $10 \mathrm{mM}$ Tris, $150 \mathrm{mM} \mathrm{NaCl}, 1 \mathrm{mM}$ EDTA, $\mathrm{pH}$ 7.4). The cell pellet $\left(2-3 \times 10^{6}\right)$ was incubated with $400 \mu l$ of cold buffer A (10 $\mathrm{mM}$ Hepes, $10 \mathrm{mM} \mathrm{KCl}, 0.1 \mathrm{mM}$ EDTA, $0.1 \mathrm{mM}$ EGTA, $1 \mathrm{mM}$ DDT, $0.5 \mathrm{mM}$ PMSF, pH 7.9) on ice for 15 min after pipetting in a yellow tip. Then, $25 \mu \mathrm{l}(10 \%)$ Nonidet P-40 was added, vortexed for $10 \mathrm{~s}$, and centrifuged for $30 \mathrm{~s}$ at $13,000 \mathrm{rpm}$. The supernatant was used as cytosol proteins. The nuclear pellet was incubated with $50 \mu \mathrm{l}$ of cold buffer B (20 mM Hepes, $0.4 \mathrm{M} \mathrm{NaCl}, 20 \%$ glycerol, $1.5 \mathrm{mM} \mathrm{MgCl}, 1$ mM EDTA, $1 \mathrm{mM}$ EGTA, $1 \mathrm{mM}$ DTT, $1 \mathrm{mM}$ PMSF, $1 \mu \mathrm{g} / \mathrm{ml}$ leupeptin, $1 \mu \mathrm{g} / \mathrm{ml}$ aprotinin, $\mathrm{pH} 7.9$ ) at $4^{\circ} \mathrm{C}$ for $15 \mathrm{~min}$ on a shaking platform with vigorous rocking. The suspension was centrifuged for $5 \mathrm{~min}$ at $4^{\circ} \mathrm{C}$ at $13,000 \mathrm{rpm}$. The supernatant was collected as nuclear proteins and protein concentration was determined with Bio-Rad assay (Bio-Rad Laboratories).

The procedure for gel mobility shift assays has been described previously $(26,32)$. In short, DNA binding was determined after incubation of $5 \mu \mathrm{g}$ of nuclear protein extract or $20 \mu \mathrm{g}$ cytosol proteins with 10 fmole of an oligonucleotide containing the HSE sequence from the Drosophila hsp70 promoter (5'-GCCTCGAATGTTCGCGAAGTTT-3') labeled with ${ }^{32} \mathrm{P}-\mathrm{dCTP}$. Reaction buffer contained $10 \mathrm{mM}$ Hepes, (pH 7.9) $1 \mathrm{mM}$ DTT, $1 \mathrm{mM}$ EDTA, $80 \mathrm{mM} \mathrm{KCl}, 4 \%$ Ficoll and $1 \mu \mathrm{g}$ poly(dIdC) (Pharmacia Biotech, Uppsala, Sweden) as a nonspecific competitor. Samples were electrophoresed through a $4 \%$ polyacrylamide gel in $0.5 \times$ TBE $(1 \times$ TBE: $89 \mathrm{mM}$ Tris, $89 \mathrm{mM}$ Boric acid, $20 \mathrm{mM}$ EDTA, pH 8.3), after which the gel was dried onto DE81 paper and exposed to autoradiographic film. Super-shift assays were performed using antibodies generated against and specific to mammalian HSF1 and HSF2 (gifts from Dr. R.I. Morimoto $[9,26]$ ). The antibodies were added to samples after the initial binding reactions between protein extracts and oligonucleotides were allowed to take place (see above).

Immunofluorescence. Immunofluorescence studies were performed as described (33) with slight modifications. In brief, subconfluent SMCs in 8-well slide chambers (cat. no. 177445; Nunc Inc., Naperville, IL) were incubated with SNP $(0.3 \mathrm{mM})$ for $3 \mathrm{~h}$, or at $42^{\circ} \mathrm{C}$ for $30 \mathrm{~min}$. Cells were washed two times with cold PBS $\left(4^{\circ} \mathrm{C}\right)$, permeabilized with $5 \%$ acetic acid/methanol at $4^{\circ} \mathrm{C}$ for $5 \mathrm{~min}$, and air-dried. Cells were incubated with the rabbit anti-HSF1 antibodies $(9,26)$ for $1 \mathrm{~h}$ at room temperature. After three washes with PBS, the cells were incubated with a swine anti-rabbit Ig-FITC conjugate (cat. no. F200; Dako, Copenhagen, Denmark) for $30 \mathrm{~min}$, rinsed, and embedded in $n$-propylgalate/glycerol (Sigma Chemical Co.). The slides were examined in an immunofluorescence microscope (Carl Zeiss, Inc., Thornwood, NY).

Preparation of hemoglobin. Pure hemoglobin was prepared as previously described (34) by adding to a 1-mM solution of rabbit hemoglobin in distilled water with $10 \mathrm{mM}$ of the reducing agent sodium dithionite. The sodium dithionite was then removed by dialysis against $100 \mathrm{vol}$ distilled water for $2 \mathrm{~h}$ at $4^{\circ} \mathrm{C}$. Hemoglobin $(10 \mu \mathrm{M})$ was added to the culture medium with or without SNP $(0.3 \mathrm{mM})$.

Cell viability assays. SMCs were plated at a density of $3 \times 10^{5}$ cells/dish $(3.5 \mathrm{~cm})$ in the medium containing $10 \%$ FCS and incubated at $37^{\circ} \mathrm{C}$ for $24 \mathrm{~h}$. The culture medium was replaced with the medium containing $0.1 \%$ FCS, and incubated for $48 \mathrm{~h}$. SMCs were then treated with heat shock $\left(42^{\circ} \mathrm{C}\right)$ for $30 \mathrm{~min}$, and recovered at $37^{\circ} \mathrm{C}$ for $4 \mathrm{~h}$. SNP $(0.5 \mathrm{mM})$ was added to the culture, and incubated at $37^{\circ} \mathrm{C}$ for $48 \mathrm{~h}$. The cells were washed three times with PBS, and fixed with methanol for $15 \mathrm{~min}$ at room temperature. The cell nuclei were stained with fluorescent dye Hoechst $33258(1 \mu \mathrm{g} / \mathrm{ml})$ for $5 \mathrm{~min}$, and were counted in a $\times 400$ field. Eight fields from each dish were randomly selected, and nuclei (80-120/field) were counted.

Statistical analysis. A paired Student's $t$ test was used to assess differences between two groups. A $P$ value less than 0.05 was considered significant.

\section{Results}

Hsp70 protein induction and $m R N A$ transcription in response to NO. To determine whether NO generated from several 
A

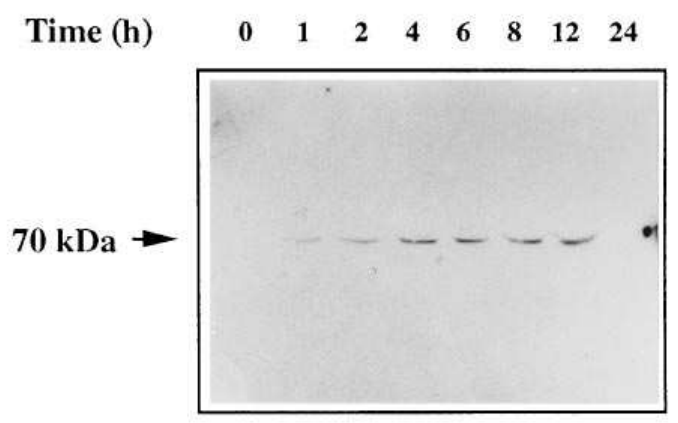

B

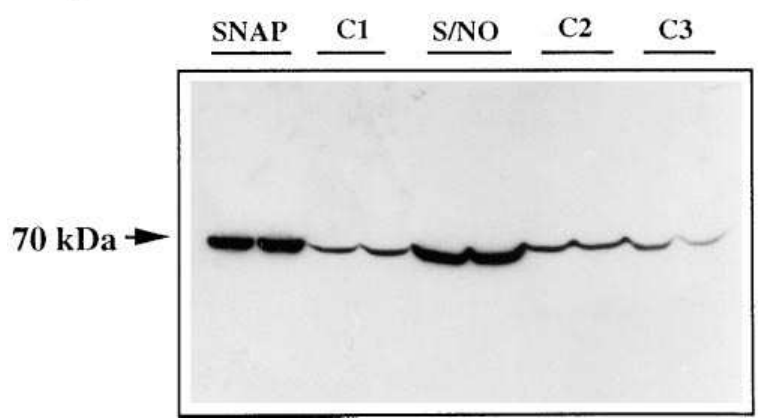

Figure 1. Western blot analysis of hsp70 protein in SMCs treated with NO donors. SMCs were dissociated from rat aortas by collagenase, and were cultivated in 199 medium. Subconfluent cells were incubated with the various NO-generating compounds indicated above at $37^{\circ} \mathrm{C}$. After incubation, cells were lysed in the buffer, protein extracts separated on $10 \%$ SDS-polyacrylamide gel, transferred to membranes, and probed using a monoclonal antibody to mammalian inducible hsp70. $A$ shows the time course of hsp70 induction in SMCs treated with SNP $(0.3 \mathrm{mM}) . B$ shows results from SMCs treated with SNAP or S/NO $(0.3 \mathrm{mM})$ for $8 \mathrm{~h}$. Controls are SMCs treated with $1 \%$ DMSO $(\mathrm{C} 1), 1 \%$ ethanol $(\mathrm{C} 2)$, or without treatment $(\mathrm{C} 3)$. compounds resulted in hsp induction, we examined hsp70 protein levels in the arterial SMCs at various times after treatment with SNP, SNAP, or S/NO. Fig. $1 A$ shows the time course of hsp70 production in response to SNP. A single protein band 70 $\mathrm{kD}$ in size was observed in proteins extracted from SMCs after incubation with the hsp70-specific antibody. The amount of $70-\mathrm{kD}$ protein increased by $2 \mathrm{~h}$ after treatment, reached a plateau between 6 and $12 \mathrm{~h}$, and declined thereafter. This time course is similar to that seen with heat shock, suggesting an early phase response (1-3). Likewise, SMCs treated with SNAP and S/NO for $8 \mathrm{~h}$ resulted in significant increases in hsp70 proteins (Fig. $1 \mathrm{~B}$ ). Since SNAP and S/NO were solublized in DMSO or ethanol, the same amount of DMSO or ethanol was added to control their effect on hsp induction; no significant difference was seen in hsp levels of SMCs treated with DMSO $(\mathrm{C} 1)$, ethanol $(\mathrm{C} 2)$, or without treatment $(\mathrm{C} 3)$ (Fig. $1 B$ ). In addition, the difference of negative controls between $A$ and $B$ (Fig. 1) is due to different amounts of proteins loaded (50 vs. $80 \mu \mathrm{g} / \mathrm{lane}$ ) and different dilution of the antibody against hsp70 (1:1000 vs. 1:3000). Thus, NO generated from three compounds causes marked hsp70 production in SMCs.

Hsp70 mRNA levels in SNP-treated SMCs were analyzed by Northern blots. As shown in Fig. 2, SNP treatment resulted in significantly increased hsp70 mRNA in SMCs. Kinetic analysis of the response revealed that the SNP-induced hsp70 mRNA expression occurred as early as $30 \mathrm{~min}$ (Fig. $2 \mathrm{~A}$ ), with maximum levels (10-fold greater than untreated control) achieved between 3 and $5 \mathrm{~h}$ after treatment and declining thereafter. To establish further the relationship between SNP treatment and hsp70 expression, we performed a doseresponse analysis of SNP-induced hsp70 mRNA accumulation. As shown in Fig. $2 \mathrm{~B}$, levels of hsp70 mRNA increased in a dose-dependent manner between 1 and $500 \mu \mathrm{M}$. Higher concentration $(1 \mathrm{mM})$ of SNP did not induce hsp70 mRNA accumulation, although the mechanism remains to be elucidated. In addition, as shown previously $(12,13,30)$, two bands of hsp70 mRNA can been seen in blot from rat tissues. Fig. 2 (bottom) shows the amount of GAPDH mRNA from the corresponding blot.
A

Time (h)

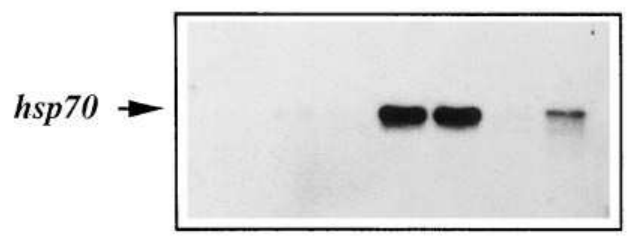

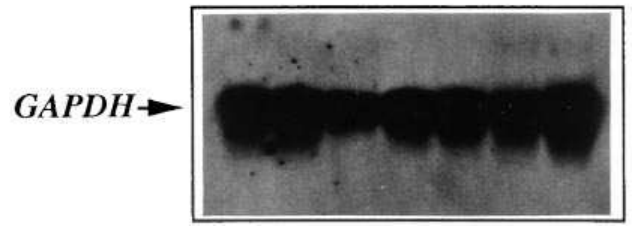

B

$\begin{array}{lllllllll}\mathrm{SNP} & (\mu \mathrm{M}) & 0 & 1 & 10 & 50 & 100 & 500 & 1000\end{array}$

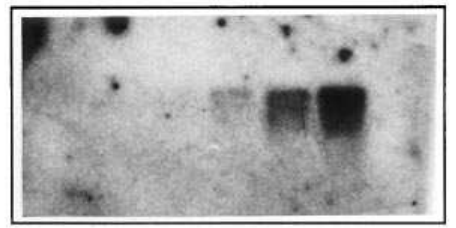

Figure 2. NO-induced $h s p 70$ mRNA expression. $A$ shows the time course of mRNA expression in SMCs treated with SNP $(0.3 \mathrm{mM})$ at $37^{\circ} \mathrm{C}$ for the indicated times, or treated with heat shock $(H)$ at $42^{\circ} \mathrm{C}$ for $30 \mathrm{~min}$. $B$ shows a concentration-dependent expression in SMCs treated with SNP at $37^{\circ} \mathrm{C}$ for $3 \mathrm{~h}$. Total RNA $(10 \mu \mathrm{g})$ was extracted from treated SMCs and assayed for hsp70 mRNA expression by Northern blot analysis. Blots were hybridized sequentially with hsp70 (top) and GAPDH (bottom) probes. Data shown are exemplary of two independent experiments. 
A

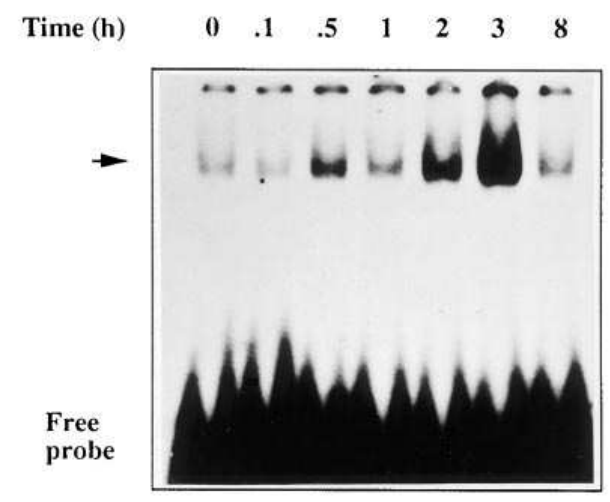

B

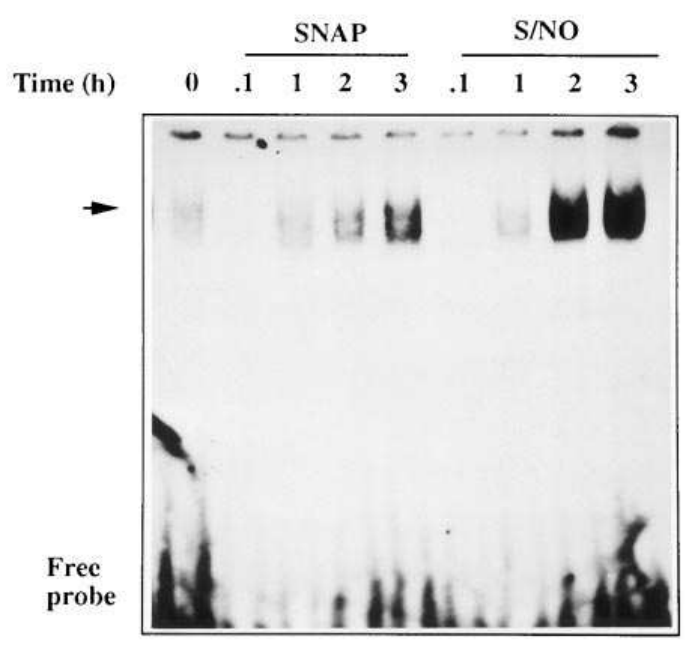

Figure 3. HSE-binding activity in protein extracts of SMCs. SMCs were treated with $\mathrm{NO}$ donors, $\mathrm{SNP}(0.3 \mathrm{mM} ; A), \mathrm{SNAP}$, or S/NO $(0.3$ $\mathrm{mM} ; B)$ at $37^{\circ} \mathrm{C}$ for the indicated times. The cells were washed and harvested with cold TBS. Nuclear proteins were prepared as described in Methods, and protein concentration was determined with a Bio-Rad assay. Protein extracts ( $5 \mu \mathrm{g}$ per lane ) were incubated with a radiolabeled oligonucleotide encompassing a 24-bp HSE of the hsp70 promoter on ice for $20 \mathrm{~min}$. Gel mobility shift assay was performed in $4 \%$ gel. Arrow indicates specific HSE-binding complexes.

HSF1 activation by NO donors. To determine whether NO induces hsp70 mRNA through HSF activation, cytosol and nuclear proteins were isolated from SMCs and assayed for the presence of HSF-binding activity. As shown in Fig. 3, levels of binding activity increased in SNP, SNAP, or S/NO-treated cells, with maximum activity $3 \mathrm{~h}$ after treatment declining by $8 \mathrm{~h}$ in SNP-treated cells. The specificity of the DNA binding was determined by a competition experiment using cold oligonucleotides. Fig. $4 A$ shows the results of a gel mobility shift assay in the presence or absence of either an unlabeled HSE, or NF$\kappa \mathrm{B}$-binding element. The SNP-induced increase in binding activity was specific for the HSE, as increased concentrations of unlabeled HSE effectively competed for binding to the factor, whereas the NF-кB-binding element did not (Fig. $4 A$ ). There is evidence to indicate that HSF1 and HSF2 mediate the hsp induction in response to different stimuli $(35,36)$; therefore, it
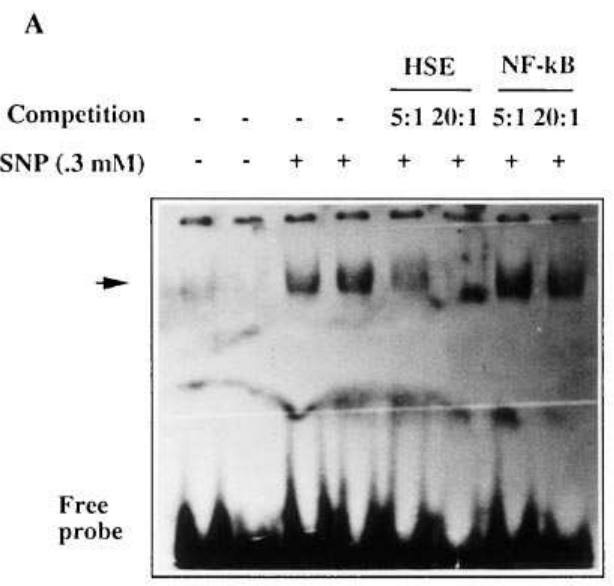

B

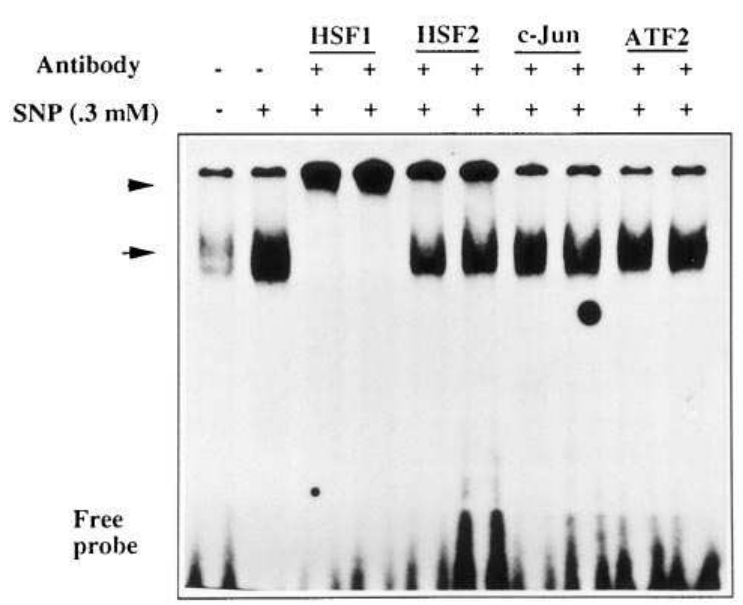

Figure 4. Specificity of HSE-binding activity in SMCs in response to SNP. Nuclear proteins from SMCs treated with SNP at $37^{\circ} \mathrm{C}$ for $3 \mathrm{~h}$ were incubated with ${ }^{32} \mathrm{P}$-labeled $\mathrm{HSE}$ oligonucleotide in the presence or absence of unlabeled oligonucleotide containing HSE or NF-кB binding element $(A)$. Note the competition by the HSE, but not the $\mathrm{NF}-\kappa \mathrm{B}$ site, containing oligonucleotide. $B$ shows results from protein extracts of SMCs incubated with radiolabeled HSE oligonucleotide with no addition $(-)$; or in the presence $(+)$ of various antibodies specific to HSF1, HSF2, c-Jun or ATF2. Specific protein-DNA complexes are indicated by the arrow. Supershifted DNA-binding complexes indicative of HSF1 protein-containing complexes are indicated by the arrowhead. Data are an example from similar results of two independent experiments.

was of interest to determine which of these HSFs were involved. We examined the composition of the DNA-binding complexes using antibodies to HSF1, HSF2, c-Jun, and ATF2. Addition of the anti-HSF1 antibody to the binding reaction resulted in a complete shift of the binding complexes to a slower migrating species, while the anti-HSF2 antibody had no effect (Fig. $4 \mathrm{~B}$ ). These results indicate the presence of HSF1, but not HSF2, proteins in the HSE-binding complexes in nuclear protein extracts of SNP-treated SMCs. Similar results were obtained with another two antibodies to unrelated transcription factors, c-Jun or ATF2.

HSF1 activation in response to heat stress involves HSF translocation from the cytoplasm to the nucleus, or relocaliza- 

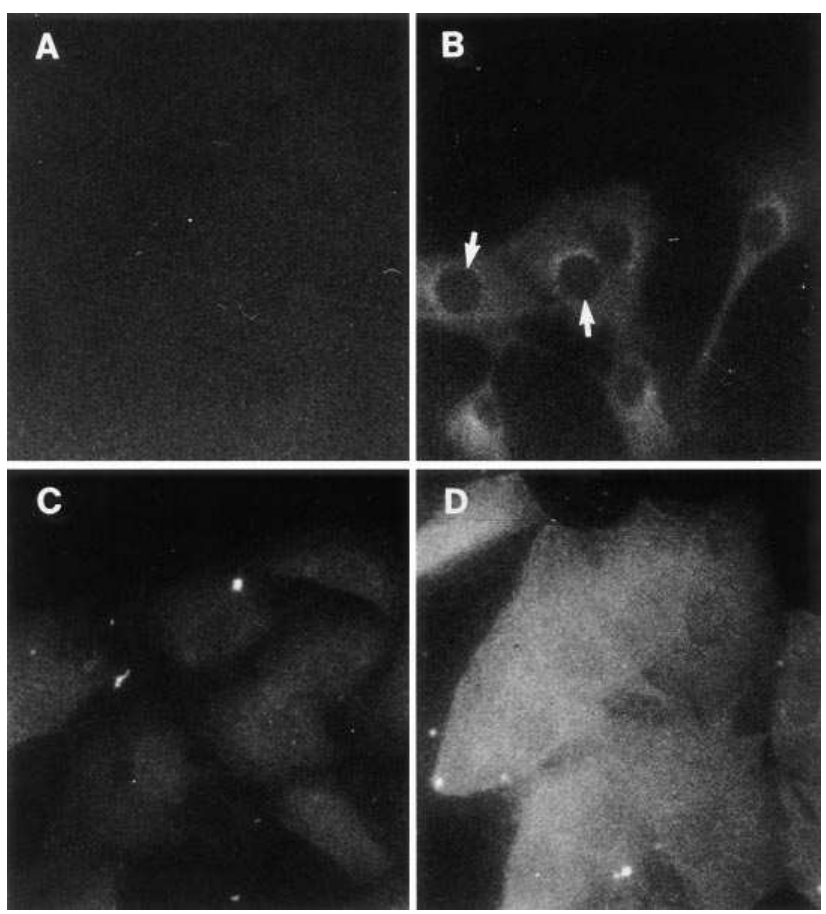

Figure 5. Immunofluorescence analysis of HSF1 proteins in SMCs. SMCs were cultured in eight-well slide bottles in the presence $(C)$ or absence $(A, B$, and $D)$ of SNP $(0.3 \mathrm{mM})$ at $37^{\circ} \mathrm{C}(A-C)$ for $3 \mathrm{~h}$, or $42^{\circ} \mathrm{C}(D)$ for $30 \mathrm{~min}$. After washing with PBS, cells were fixed with cold $5 \%$ acetone/methanol for $30 \mathrm{~min}$, air-dried, and incubated with the rabbit anti-HSF1 antibodies $(B-D)$ or normal mouse $\operatorname{Ig}(A)$ for $1 \mathrm{~h}$. The reaction was visualized by anti-rabbit Ig-FITC conjugated swine $\mathrm{Ig} ; \times 250$.

tion within the nucleus $(4,5)$. To determine whether such translocation occurs in SNP-treated cells, immunofluorescence analysis was performed using anti-HSF1 antibody. Both nuclear and cytoplasmic staining was observed in SNP-treated SMCs (Fig. $5 C$ ), while the majority of immunofluorescence staining was in the cytoplasm in untreated controls (Fig. $5 \mathrm{~B}$ ). As expected, heat shock induced HSF1 translocation in SMCs (Fig. $5 \mathrm{D}$ ). Results from gel mobility shift assays with cytosol proteins showed no significant binding activity (data not shown). When nuclear proteins from NO-treated or untreated SMCs were analyzed by Western blot, differences in protein level and mobility of HSF1 were observed (Fig. 6). In untreated cells, HSF1 appeared to be present in nuclei at low levels evidenced by weaker signal and migrated on SDS-polyacrylamide gels as an $\sim 70 \mathrm{kD}$ protein. NO treatment and heat stress resulted in an increased HSF1 in nuclei and a shift to higher molecular weight species $0.5-3 \mathrm{~h}$ after treatment (Fig. 6 ). The findings indicate that translocation and phosphorylation is necessary for HSF activation in response to NO stimulation.

Inhibition of NO-induced hsp expression. It is established that NO evokes SMC relaxation through the cGMP-dependent signal pathway. Since accumulation of cellular cGMP depends on the presence of calcium (37), it would be interesting to test whether calcium is necessary for SNP-induced HSFHSE binding, or whether this response is mediated by the cGMP signal pathway. The cell-permeable calcium chelator acetoxymethyl ester of EGTA was added to culture $30 \mathrm{~min}$ be-

\section{$42^{\circ} \mathrm{C}$ Control SNP $(0.3 \mathrm{mM}) \quad$ S/NO $(0.3 \mathrm{mM})$ \\ Time $\overline{30^{\prime} 30^{\prime}} \overline{-}-\overline{10^{\prime} \text { 1h } 2 \mathrm{~h} 3 \mathrm{~h}} \overline{10^{\prime} \text { 1h } 2 \mathrm{~h} 3 \mathrm{~h}}$}

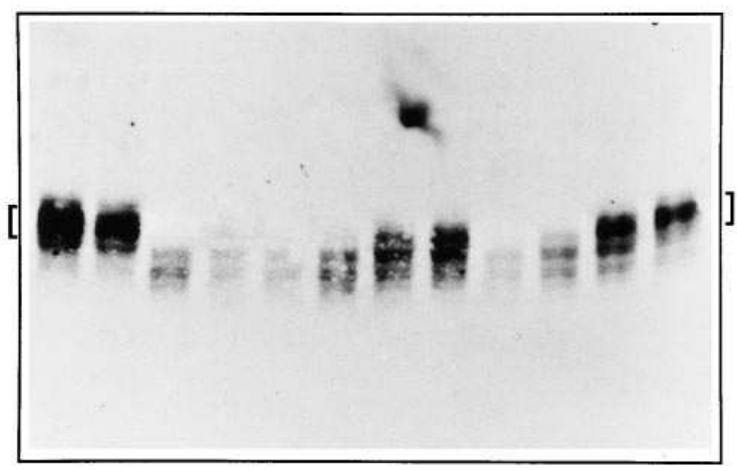

Figure 6. Western analysis of HSF1 protein in control and NOtreated cells. Nuclear proteins prepared from SMCs treated with heat shock $\left(42^{\circ} \mathrm{C}\right.$ for $\left.30 \mathrm{~min}\right), \mathrm{SNP}$, or $\mathrm{S} / \mathrm{NO}$ for the indicated time were analyzed by Western immunoblotting for HSF1 protein. Brackets indicates the position of slower migrating forms of HSF1 protein.

fore SNP treatment. Data in Fig. $7 A$ indicate that EGTA did not significantly inhibit SNP-induced HSF-HSE binding, suggesting that the NO-induced response may be independent of cGMP-mediated signaling. Hemoglobin is a well-established antagonist of NO (38), and has been used to determine whether the effects of SNP may be due to NO generation (39). Therefore, we determined the effect of SNP on HSF activation in the presence of hemoglobin; hemoglobin alone had no significant effect on HSF activation, and abolished the SNPmediated HSF activation in SMCs (Fig. $7 A$ ), indicating that HSF activation by SNP is mediated by NO per se released from the compound.

DTT, a thiol-reducing agent, readily permeates cell membranes, and is a protective reagent for sulfhydryl groups. Experiments with SNP-activated HSF binding in the presence of DTT showed that DTT inhibited SNP-mediated HSF-HSE binding in SMCs (Fig. 7 B). These results support the notion that NO-induced HSF activation may involve protein denaturation or damage. It has been suggested that protein synthesis is involved in HSF activation in heat-stressed cells because translation inhibitors can prevent $\operatorname{HSF}$ binding $(4,5)$. Cycloheximide, at a concentration that inhibited cellular protein synthesis, abolished HSF binding to HSE in response to SNP (Fig. 7 $B)$. As confirmed, cycloheximide completely inhibited heat shock-induced HSF activation. Thus, the SNP-induced HSFDNA binding, similar to that induced by heat stress, also involves protein synthesis. To verify further the effects of DTT and cycloheximide on hsp expression, transcription and translation of hsp70 were determined in SMCs treated with SNP in the presence of these inhibitors. The results shown in Fig. 8 provide evidence that both agents significantly inhibited hsp70 mRNA and protein induction mediated by SNP.

Effect of heat shock on SMC survival after SNP exposure. Fukuo et al. (40) have shown that NO generated from SNP causes SMC apoptosis. To investigate the potential physiological role of hsps in mediating the protective response to NO stress, we undertook a comparative analysis of cell survival after SNP exposure in SMCs with or without preincubation at $42^{\circ} \mathrm{C}$ for $30 \mathrm{~min}$. After $48 \mathrm{~h}$ incubation with SNP, a population 


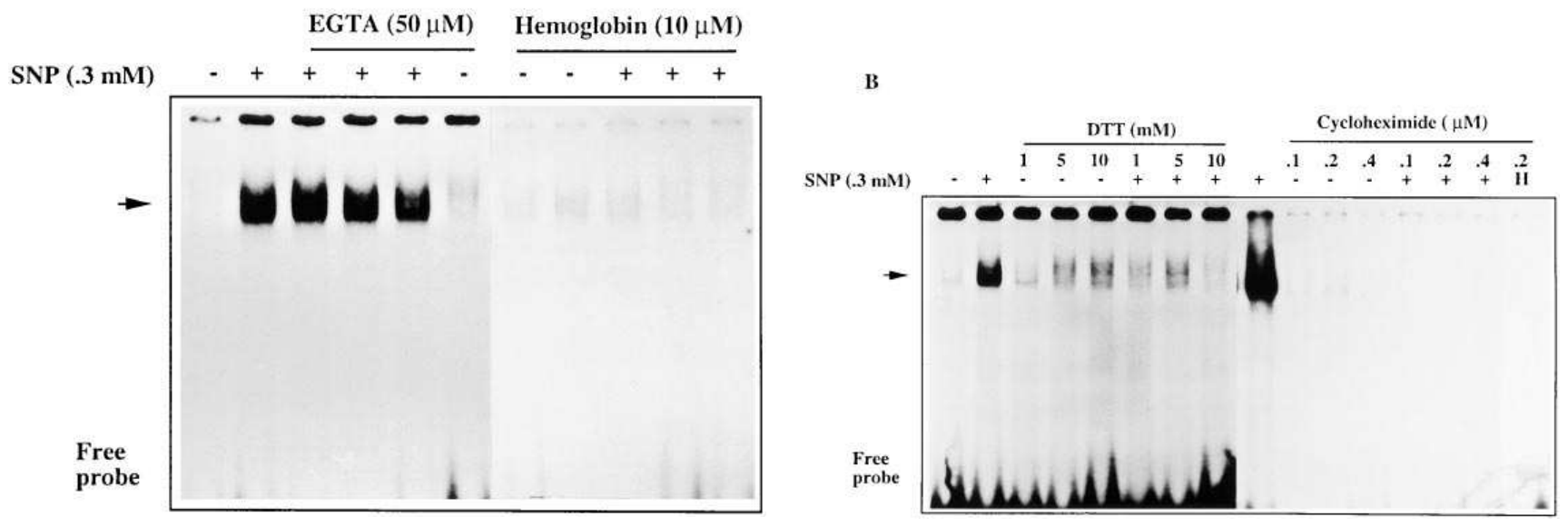

Figure 7. Effects of inhibitors on HSE-binding activity in nuclear proteins of SMCs. $(A)$ SMCs were treated with EGTA or hemoglobin in the presence $(+)$ or absence $(-)$ of SNP at $37^{\circ} \mathrm{C}$ for $3 \mathrm{~h}$, washed, and harvested with the cold buffer. (B) SMCs were pretreated with DTT or cycloheximide at $37^{\circ} \mathrm{C}$ for $30 \mathrm{~min}$, and then medium was replaced by SNP-containing medium. The cells were incubated at $37^{\circ} \mathrm{C}$ for another $3 \mathrm{~h}$. Protein extracts were incubated with a radiolabeled oligonucleotide HSE. The arrow indicates specific HSE-binding complexes. $H$, SMCs treated with $42^{\circ} \mathrm{C}$ for $30 \mathrm{~min}$.

A
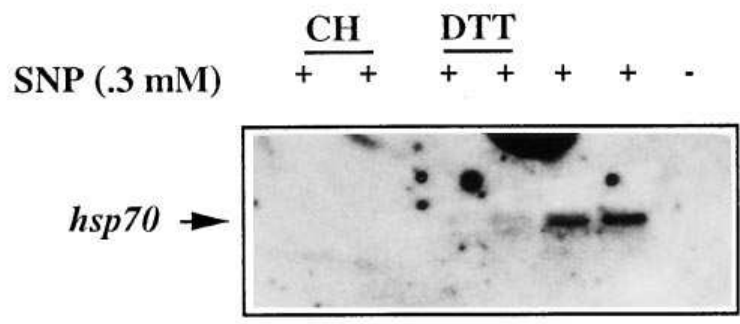

B

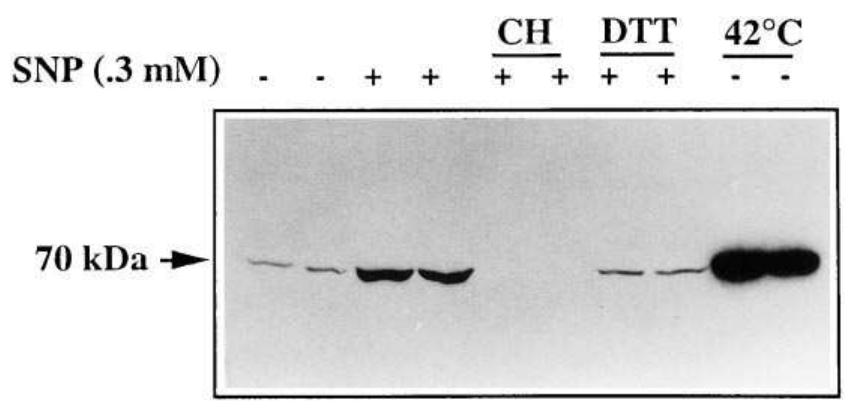

Figure 8. Effects of inhibitors on NO-induced $h s p 70$ mRNA $(A)$ or hsp70 proteins $(B)$. SMCs were treated with DTT or cycloheximide at $37^{\circ} \mathrm{C}$ for $30 \mathrm{~min}$, and then with SNP at $37^{\circ} \mathrm{C}$ for $3 \mathrm{~h}(A)$ or for $8 \mathrm{~h}(B)$ after replacement of medium. Total RNA $(10 \mu \mathrm{g})$ was extracted from cultured cells and assayed for hsp70 mRNA expression by Northern analysis. Blots were hybridized sequentially with hsp70 $(A)$ and GAPDH (data not shown) probes. Western blot analysis of hsp70 protein in SMCs was treated as described above. For heat shock, cells were incubated at $42^{\circ} \mathrm{C}$ for $20 \mathrm{~min}$, and were continually incubated at $37^{\circ} \mathrm{C}$ for up to $8 \mathrm{~h}$. After incubation, cells were lysed in the buffer, and whole cell protein extracts were separated on $10 \%$ SDS-polyacrylamide gel, transferred to membranes, and probed using a monoclonal antibody to mammalian inducible hsp70. Data shown are exemplary from similar results of two independent experiments. of cells were dead or dying, characterized by detachment from the surface of culture dishes. These cells were washed away, and remaining cells were stained with Hoechst and counted under the fluorescence microscope. Data shown in Fig. 9 provide evidence that heat shock significantly increased SMC survival from SNP-induced cell death. SNP treatment resulted in morphological changes in cell nuclei, and decreased the number of living SMCs (Fig. 9). Thus, pretreatment with elevated temperature that shows hsp70 induction (Fig. 8) protected SMCs from NO-induced damage.

\section{Discussion}

We have demonstrated that NO generated from several compounds induces hsp70 expression in arterial SMCs, and have provided evidence that this effect relies on the HSF1 activation. Recently, reports from others $(41,42)$ have also demonstrated hsp70 protein accumulation in cultured Hep G2 and hepatocytes treated with NO donors. The nature of the primary signal that activates HSF1 in response to heat shock or stress remains to be clarified. Current studies support a model for regulating heat shock response in which the hsps themselves negatively regulate heat shock gene expression via an autoregulatory loop $(4,5)$. Under a nonstressful condition, HSF1 is maintained in a monomeric form through transient interactions with both constitutive (hsc70) and inducible (hsp70) hsps. During heat shock or other stresses, the accumulation of misfolded proteins causes the hsp70 mobilization, resulting in the free pool of hsp70 and consequent removal of the negative regulatory influence on HSF activation. The released HSF is phosphorylated and assembles into trimers, acquires DNA binding activity, and leads to elevated hsp70 mRNA transcripts. During NO stimulation, multiple and complex pathophysiological changes occur in SMCs, including protein damage or modifications due to the cytotoxic effect of $\mathrm{NO}(19,34$, 43-45). Thus, NO- and heat shock-induced hsp70 productions share many similarities in activation of HSF1 and regulation of hsp70 gene expression. 


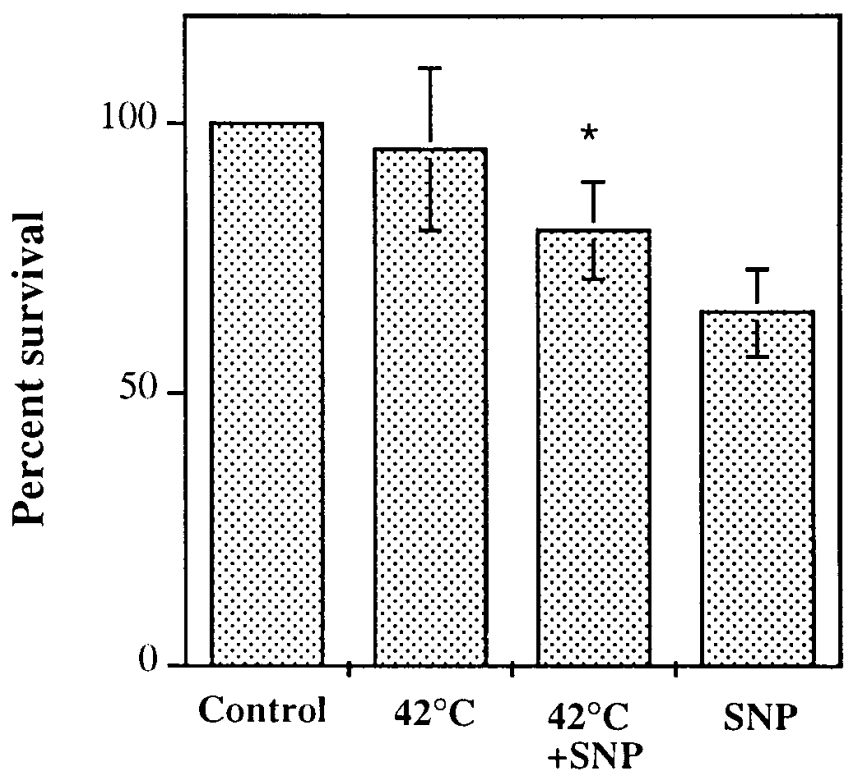

Figure 9. Comparative effect of heat shock and SNP on SMC viability. SMCs were preincubated with the medium containing $0.1 \%$ bovine calf serum for $48 \mathrm{~h}$, were treated with heat shock $\left(42^{\circ} \mathrm{C}\right)$ for 30 min, and were incubated at $37^{\circ} \mathrm{C}$ for $4 \mathrm{~h}$. SMCs with or without heat treatment were incubated with SNP $(0.5 \mathrm{mM})$ at $37^{\circ} \mathrm{C}$ for $48 \mathrm{~h}$, washed three times with PBS, and fixed with methanol for $15 \mathrm{~min}$ at room temperature. The cell nuclei were stained with fluorescent dye Hoechst $33258(1 \mu \mathrm{g} / \mathrm{ml})$ for $5 \mathrm{~min}$ and counted. The graph is \% means \pm SD of three experiments. *Significant difference from SMCs treated with SNP alone.

Hightower (46) has proposed that proteotoxicity is an important trigger for the heat shock response. Microinjecting denatured proteins into Xenopus laevis oocytes is sufficient to elicit the heat shock response $(47,48)$. Subsequent studies showed that hsp prevents aggregation of denatured proteins, resolubilizes protein aggregates that have already formed, and assists in refolding denatured proteins (49-53). The ability of hsps to retain denatured proteins in soluble form is a critical step in proteolysis of damaged proteins (49-53). Thus, hsp serves as a switching point in recognition of reversibly and irreversibly damaged proteins. Meanwhile, accumulating evidence indicates that NO stimulates the $S$-nitrosylation of numerous proteins (20), by interaction with a free sulfhydryl group to form a rapidly decaying $S$-nitrosothiol; if a pair of such groups are in close proximity (termed vicinal thiols), NO may serve as an oxidizing agent to form a disulfide bond, producing a relatively persistent covalent modification (54). Such modification occurs in all iron-sulfur enzymes, which are essential for cell survival. In the present study, NO-induced HSF1 activation was completely blocked by DTT, a disulfide-reducing agent. Our results, taken together with observations by others, support the conclusion that HSF activation may, in part, result from NO-induced protein damages.

Cycloheximide abolished HSF1 activation and hsp70 transcription by NO, suggesting, in agreement with other studies in heat shock, that ongoing protein synthesis plays a role $(52,55-$ 57). Hsps were proposed to function as molecular chaperones during protein folding, and to prevent aggregation of nascent polypeptide chains $(49,58)$. It is likely that blocking protein synthesis with cycloheximide releases hsp70 from folding na- scent polypeptides, thus increasing the hsp pool available to handle the malfolded proteins that precipitated the need for HSF1 activation $(49,59)$. Alternatively, the newly synthesized polypeptide pool may be more susceptible to NO damage (55, 59). Elucidating the mechanism underlying the role of nascent peptides and protein synthesis in HSF1 activation by NO will require further study.

Because DTT inhibits protein synthesis (60), it could be argued that, like cycloheximide, all or part of the DTT effect on HSF activation is due to inhibition of protein synthesis. There are two reasons to refute this theory; first, DTT prevented HSF-DNA binding and hsp70 expression under conditions that did not affect protein synthesis; we have incubated SMCs with DTT for 30 min before NO was added, and this short time period did not significantly inhibit protein synthesis (61). Second, concentrations of DTT that had no effect on protein synthesis did not diminish HSF1 activation by moderate heat shock (data not shown), whereas cyclohexmide blocked HSF1 activation. Therefore, the effects of DTT and cycloheximide on HSF1 activation by NO can be segregated in SMCs.

What is the role of the stress-induced hsp70 expressed in SMCs? The data presented here and observed by others suggest that it could play a role in the repair of denatured proteins modified by NO, and in folding of nascent polypeptide chains. Whatever the precise function, hsp70 is likely to be important in maintaining SMC homeostasis during NO stress. Induction of hsp70 by pretreatment of SMCs with higher temperature results in their protection from NO-induced death, suggesting that the response has a direct pathophysiological relevance.

In animal models, we have shown recently that acute elevation in blood pressure induced by hypertensive agents or restraint stress rapidly leads to hsp70 expression preceded by HSF1 activation (62). How acute hypertension triggers HSF1 activation in vivo is currently unknown. Given the fact that mechanical stress results in NO release from endothelial cells (21-23), we postulate that NO released from the arterial wall in response to hemodynamic stress may, at least in part, be responsible for hsp70 production in aortas. Similarly, increased expression of hsps in atherosclerotic lesions may also relate to disturbed NO production. Extensive nitration of proteins in atherosclerotic lesions (63), which can be a signal for HSF1 activation, occurs. Several groups have documented that NO initiates lipid peroxidation in LDL to form oxLDL (64), an inducer for hsp70 expression (65), due to formation of peroxynitrite and other intermediates that react with tyrosine residues to produce nitrosotyrosines (66-68). Thus, augmentation of hsp70 in both disease conditions is associated with inappropriate NO production.

Recent studies have focused on the protective role of hsp70 in cardiovascular disorders (69). Transgenic mice overexpressing hsp70 show enhanced resistance to ischemic injury in heart $(70,71)$. Treatment with NO generated from compounds protects heart during acute myocardial ischemia and reperfusion (72-74), possibly via NO-induced hsp70 accumulation. In the arterial wall, increased expression of hsp70 in atherosclerotic lesions may aid SMC survival (75). Our studies raise additional questions with regard to the role of hsps in vascular tissue, i.e., would overexpression of hsp70 in the arterial wall confer resistance to hemodynamic stress? And what relationship exists in vivo between NO production and hsp70 expression? We believe that further research on the answers will result in valuable clinical application. 


\section{Acknowledgments}

We thank Dr. R.I. Morimoto, Northwestern University, Evanston, IL, for providing us the antibodies against HSF1 and HSF2; G. Sturm and A. Jenewein for excellent technical assistance, and T. Öttl for the preparation of photographs.

This work was supported by grants P11615-MED (to Q. Xu) and P10677-MED (to G. Wick) from the Austrian Science Foundation.

\section{References}

1. Lindquist, S., and E.A. Craig. 1988. The heat-shock proteins. Annu. Rev. Genet. 22:631-677.

2. Morimoto, R.I., A. Tissieres, and C. Georgopoulous. 1990. The stress response, function of the proteins, and perspectives. In Stress Proteins in Biology and Medicine. R.I. Morimoto, A. Tissieres, and C. Georgopoulous, editors. Cold Spring Harbor Laboratory Press. Cold Spring Harbor, NY. 1-13.

3. Schlesinger, M.J. 1990. Heat shock proteins. J. Biol. Chem. 265:1211112114.

4. Lis, J., and C. Wu. 1993. Protein traffic on the heat shock promoter: parking, stalling, and trucking along. Cell. 74:1-4.

5. Morimoto, R.I. 1993. Cells in stress: Transcriptional activation of heat shock genes. Science (Wash. DC). 259:1409-1410.

6. Sorger, P.K. 1991. Heat shock factor and the heat shock response. Cell. 65:363-366.

7. Welch, W.J. 1993. Heat shock proteins functioning as molecular chaperones: their roles in normal and stressed cells. Philos. Trans. R. Soc. Lond. B. Biol. Sci. 339:327-333.

8. Kim, D., H. Ouyang, and G.C. Li. 1995. Heat shock protein hsp70 accelerates the recovery of heat-shocked mammalian cells through its modulation of heat shock transcription factor HSF1. Proc. Natl. Acad. Sci. USA. 92:2126-2130.

9. Sistonen, L., K.D. Sarge, and R.I. Morimoto. 1994. Human heat shock factor 1 and 2 are differentially activated and can synergistically induce hsp70 gene transcription. Mol. Cell. Biol. 14:2087-2099.

10. Fawcett, T.W., S.L. Sylveste, K.D. Sarge, R.I. Morimoto, and N.J. Holbrook. 1994. Effects of neurohormonal stress and aging on the activation of mammalian heat shock factor 1. J. Biol. Chem. 269:32272-32278.

11. Green, M., T.J. Schuetz, E.K. Sullivan, and R.E. Kingston. 1995. A heat shock-responsive domain of human HSF1 that regulates transcription activation domain function. Mol. Cell. Biol. 15:3354-3362.

12. Xu, Q., D. Li, N.J. Holbrook, and R. Udelsman. 1995. Acute hypertension induces heat shock protein 70 gene expression in rat aorta. Circulation. 92: 1223-1229.

13. Udelsman, R., M.J. Blake, and N.J. Holbrook. 1991. Molecular response to surgical stress: specific and simultaneous heat shock protein induction in the adrenal cortex, aorta, and vena cava. Surgery. 110:1125-1131.

14. Berberian, P.A., W. Myers, M. Tytell, V. Challa, and M.G. Bond, 1990. Immunohistochemical localization of heat shock protein-70 in normal-appearing and atherosclerotic specimens of human arteries. Am. J. Pathol. 136:71-80.

15. Xu, Q., R. Kleindienst, W. Waitz, H. Dietrich, and G. Wick. 1993. Increased expression of heat shock protein 65 coincides with a population of infiltrating $\mathrm{T}$ lymphocytes in atherosclerotic lesions of rabbits specifically responding to heat shock protein 65. J. Clin. Invest. 91:2693-2702.

16. Kleindienst, R., Q. Xu, J. Willeit, F.R. Waldenberger, S. Weimann, and G. Wick. 1993. Immunology of atherosclerosis: Demonstration of heat shock protein 60 expression and T lymphocytes bearing $\alpha / \beta$ or $\gamma / \delta$ receptor in human atherosclerotic lesions. Am. J. Pathol. 142:1927-1937.

17. Johnson A.D., P.A. Berberian, and M.G. Bond. 1990. Effect of heat shock proteins on survival of isolated aortic cells from normal and atherosclerotic cynomolgus macaques. Atherosclerosis. 84:111-119.

18. Bredt, D.S., and S.H. Snyder. 1994. Nitric oxide: a physiologic messenger molecule. Annu. Rev. Biochem. 63:175-195.

19. Fukuo, K., T. Inoue, S. Morimoto, T. Nakahashi, O. Yasuda, S. Kitano, R. Sasada, and T. Ogihara. 1995. Nitric oxide mediates cytotoxicity and basic fibroblast growth factor release in cultured vascular smooth muscle cells. A possible mechanism of neovascularization in atherosclerotic plaques. J. Clin. Invest. 95:669-676.

20. Brunne, B., S. Mohr, and U.K. Messmer. 1996. Protein thiol modification and apoptotic cell death as cGMP-independent nitric oxide (NO) signaling pathways. Rev. Physiol. Biochem. Pharmacol. 127:1-30.

21. Moncada, S., and E.A. Higgs. 1995. Molecular mechanisms and therapeutic strategies related to nitric oxide. FASEB J. 9:1319-1330.

22. Kanai, A.J., H.C. Strauss, G.A. Truskey, A.L. Crews, S. Grunfeld, and T. Malinski. 1995. Shear stress induces ATP-independent transient nitric oxide release from vascular entothelial cells, measured directly with a porphyrinic microsensor. Circ. Res. 77:284-293.

23. Topper, J.N., J. Cai, D. Falb, and M.A. Gimbrone, Jr. 1996. Identification of vascular endothelial genes differentially responsive to fluid mechanical stimuli: Cyclooxygenase-2, manganese superoxide dismutase, and endothelial cell nitric oxide synthase are selectively upregulated by steady laminar shear stress. Proc. Natl. Acad. Sci. USA. 93:10417-10422.

24. Ross, R., and B. Kariya. 1980. Smooth muscle cells in culture. In Handbook of Physiology: Circulation, Vascular Smooth Muscle. D.F. Bohr, A.P. Somlyo, and H.V. Sparks, editors. American Phyiological Society, Bethesda, MD. 69-91.

25. Welch, W.J., and G.P. Suhan. 1986. Cellular and biochemical events in mammalian cells during and after recovery from physiological stress. J. Cell Biol. 103:2035-2052.

26. Xu, Q., L. Ganju, T.W. Fawcett, and N.J. Holbrook. 1996. Vasopressininduced heat-shock protein expression in renal tubular cells. Lab. Invest. 74: 178-187.

27. Chomzcynski, P., and N. Sacchi. 1987. Single-step method of RNA isolation by acid guanidinium thiocyanate-phenol-chloroform extraction. Anal. Biochem. 162:156-159.

28. Udelsman, R., M.J. Blake, C.A. Stagg, D. Li, D.J. Putney, and N.J. Holbrook. 1993. Vascular heat shock protein expression in response to stress. $J$. Clin. Invest. 91:465-473.

29. Dugaiczyk, A., J.A. Haron, E.M. Stone, O.E. Dennison, K.N. Rothblum, and R.J. Schwartz. 1983. Cloning and sequencing of a deoxyribonucleic acid copy of glyceraldehyde-3-phosphate dehydrogenase messenger ribonucleic acid isolated from chicken muscle. Biochemistry. 22:1605-1613.

30. Fornace, A.J., I. Alamo, Jr., M.C. Hollander, and E. Lamoreaux. 1989. Induction of heat shock protein transcripts and B2 transcripts by various stresses in Chinese hamster cells. Exp. Cell Res. 182:61-74.

31. Schreiber, E., P. Mathias, M.M. Müller, and W. Schaffner. 1989. Rapid detection of octamer binding proteins with 'mini-extracts', prepared from a small number of cells. Nucleic Acids Res. 17:6419.

32. Xu, Q., Y. Liu, M. Gorospe, R. Udelsman, and N.J. Holbrook. 1996. Acute hypertension activates mitogen-activated protein kinases in arterial wall. J. Clin. Invest. 97:508-514.

33. Xu, Q., G. Schett, C.S. Seitz, Y. Hu, R.S. Gupta, and G. Wick. 1994. Surface staining and cytotoxic activity of heat-shock protein 60 antibody on stressed aortic endothelial cells. Circ. Res. 75:1078-1085.

34. Martin, W., G.M. Villani, D. Jothianandan, and R.F. Furchgott. 1985. Selective blockade of endothelium-dependent and glyceryl trinitrate-induced relaxation by hemoglobin and by methylene blue in the rabbit aorta. J. Pharmacol. Exp. Ther. 232:708-716.

35. Sistonen, L., K.D. Sarge, K. Abravaya, B. Phillips, and R.I. Morimoto. 1992. Activation of heat shock factor 2 during hemin-induced differentiation of human erythroleukemia cells. Mol. Cell. Biol. 12:4104-4111.

36. Kroeger, P.E., K.D. Sarge, and R.I. Morimoto. 1993. Mouse heat shock transcription factor 1 and 2 prefer a trimeric binding site but interact differently with the HSP70 heat shock element. Mol. Cell. Biol. 13:3370-3383.

37. Thompson, S.H., C. Mathes, and A.A. Alousi. 1995. Calcium requirement for cGMP production during muscarinic activation of N1E-115 neuroblastoma cells. Am. J. Physiol. 269(4 Pt. 1):C979-C985.

38. Murad, F., C.K. Mittal, W.P. Arnold, S. Katsuki, and K. Kimura. 1978. Guanylate cyclase: activation by azide, nitro compounds, and nitric oxide and inhibited by hemoglobin and myoglobin. Adv. Cyclic Nucleotide Res. 9:145-158.

39. Kolpakov, V., D. Gordon, and T.J. Kulik. 1995. Nitric oxide-generating compounds inhibit total protein and colllagen synthesis in cultured vascular smooth muscle cells. Circ. Res. 76:305-309.

40. Fukuo, K., S. Hata, T. Suhara, T. Nakahashi, Y. Shinto, Y. Tsujimoto, S. Morimoto, and T. Ogihara. 1996. Nitric oxide induces upregulation of Fas and apoptosis in vascular smooth muscle. Hypertension (Dallas). 27:823-826.

41. Malyshev, Y.I., A.V. Malugin, L.Y. Golubeva, T.A. Zenina, E.B. Manukhina, V.D. Mikoyan, and A.F. Vanin. 1996. Nitric oxide donor induces HSP70 accumulation in the heart and in cultured cells. FEBS Lett. 391:21-23.

42. Kim, Y.-M., M.E. de Vera, S.C. Watkins, and T.R. Billiar. 1997. Nitric oxide protects cultured rat hepatocytes from tumor necrosis factor- $\alpha$-induced apoptosis by inducing heat shock protein 70 expression. J. Biol. Chem. 272: 1402-1411.

43. Ignarro, L.J., H. Lippton, J.C. Edwards, H.W. Baricons, A.L. Hyman, P.J. Kadowitz, and C.A. Gruetter. 1981. Mechanism of vascular smooth muscle relaxation by organic nitrates, nitrites, nitro-prusside, and nitric oxide: evidence for the involvement of S-nitrosothiols as active intermediates. J. Pharmacol. Exp. Ther. 218:739-749.

44. Garg, U.C., and A. Hassid. 1989. Nitric oxide-generating vasodilators inhibit mitogenesis. J. Clin. Invest. 83:1774-1777.

45. Lipton, S.A., Y.-B. Choi, Z.-H. Pan, S.Z. Lei, H.-S.V. Chen, N.J. Sucher, J. Loscalzo, D.J. Singel, and J.S. Stamler. 1993. A redox-based mechanism for the neuroprotective and neurodestructive effects of nitric oxide and related nitroso-compounds. Science (Wash. DC). 364:626-632.

46. Hightower, L.E. 1991. Heat shock, stress proteins, chaperones, and proteotoxicity. Cell. 66:191-197.

47. Ananthan, J., A.L. Goldberg, and R. Voellmy. 1986. Abnormal proteins serve as eukaryotic stress signals and trigger the activation of heat shock genes. Science (Wash. DC). 232:522-524.

48. Mifflin, L.C., and R.E. Cohen. 1994. Hsc70 moderates the heat shock (stress) response in Xenopus laevis oocytes and binds to denatured protein inducers. J. Biol. Chem. 269:15718-15723.

49. Beckmann, R.P., M. Lovett, and W.J. Welch. 1992. Examining the function and regulation of hsp 70 in cells subjected to metabolic stress. J. Cell Biol. 
117:1137-1150.

50. Parsell, D.A., A.S. Kowal, M.A. Singer, and S. Lindquist. 1994. Protein disaggregation mediated by heat-shock protein Hsp104. Nature (Lond.). 372: $475-478$

51. Geogopoulos, C., and W.J. Welch. 1993. Role of the major heat shock proteins as molecular chaperones. Annu. Rev. Cell Biol. 9:601-634.

52. Welch, W.J. 1992. Mammalian stress response: cell physiology, structure/function of stress proteins, and implications for medicine and disease. Physiol. Rev. 72:1063-1081.

53. Kandror, O., L. Busconi, M. Sherman, and A.L. Goldberg. 1994. Rapid degradation of an abnormal protein in Escherichia coli involves the chaperones GroEL and GroES. J. Biol. Chem. 269:23575-23582.

54. Ignarro, L.J. 1990. Biological actions and properties of endotheliumderived nitric oxide. Annu. Rev. Pharmacol. Toxicol. 30:535-560.

55. Kroes, R.A., K. Abravaaya, J. Seidenfeld, and R.I. Morimoto. 1991. Selective activation of human heat shock gene transcription by nitrosourea antitumor drugs mediated by isocyanate-induced damage and activation of heat shock transcription factor. Proc. Natl. Acad. Sci. USA. 88:4825-4829.

56. Mosser, D.D., N.G. Theodorakis, and R.I. Morimoto. 1988. Coordinate changes in heat shock element-binding activity and HSP70 gene transcription rates in human cells. Mol. Cell Biol. 8:4736-4744.

57. Armin, J., M. Fernandez, J. Ananthan, J.T. Lis, and R. Voellmy. 1994. Cooperative binding of heat shock transcription factor to the Hsp70 promoter in vivo and in vitro. J. Biol. Chem. 269:4804-4811.

58. Sherman, M.Y., and A.L. Goldberg. 1993. Heat shock of Escherichia coli increases binding of dnaK (the hsp70 homolog) to polypeptides by promoting its phosphorylation. Proc. Natl. Acad. Sci. USA. 90:8648-8652.

59. Hansen, W.J., V.R. Lingappa, and W.J. Welch. 1994. Complex environment of nascent polypeptide chains. J. Biol. Chem. 269:16610-16613.

60. Prostko, C.R., M.A. Brostrom, E.M. Malara, and C.O. Brostrom. 1992. Phosphorylation of eukaryotic initiation factor (eIF) 2 alpha and inhibition of eIF-2B in GH3 pituitary cells by perturbants of early protein processing that induce GRP78. J. Biol. Chem. 267:16751-16754.

61. Liu, H., R. Lightfoot, and J.L. Stevens. 1996. Activation of heat shock factor by alkylating agents is triggered by glutathione depletion and oxidation of protein thiols. J. Biol. Chem. 271:4805-4812.

62. Xu, Q., T.W. Fawcett, R. Udelsman, and N.J. Holbrook. 1996. Activation of heat shock transcription factor 1 in rat aorta in response to high blood pressure. Hypertension (Dallas). 28:53-57.

63. Beckman, J.S., J. Chen, H. Ischiropoulos, and J.P. Crow. 1994. Exten- sive nitration of protein tyrosines in human atherosclerosis detected by immunohistochemistry. Biol. Chem. Hoppe-Seyler. 375:81-88.

64. Darly-Usmar, V.M. 1992. The simultaneous generation of superoxide and nitric oxide can initiate lipid peoxidation in human low density lipoprotein. Free Rad. Res. Commun. 17:9-20.

65. Zhu, W.M., P. Roma, L. Barberi, D. Astore, R. Chiesa, and A.L. Catapano. 1996. Human endothelial cells exposed to oxidized LDL express hsp70 only when proliferating. Arterioscler. Thromb. Vasc. Biol. 16:1104-1111.

66. White, C.R., T.A. Brock, L.Y. Chang, J. Crap, P. Briscoe, D. Ku, and B.A. Freeman. 1994. Superoxide and peroxynitrite in atherosclerosis. Proc. Natl. Acad. Sci. USA. 91:1044-1048.

67. Bult, H. 1996. Nitric oxide and atherosclerosis: possible implications for therapy. Mol. Med. Today. 2:510-518.

68. Eiserich, J.P., C.E. Cross, A.D. Jones, B. Halliwell, and A. van der Vliet. 1996. Formation of nitrating and chlorinating species by reaction of nitrite with hypochlorous acid. J. Biol. Chem. 271:19199-19208.

69. Xu, Q., and G. Wick. 1996. The role of heat shock proteins in protection and pathophysiology of the arterial wall. Mol. Med. Today. 2:372-379.

70. Marber, M.S., R. Mestril, S.H. Chi, M.R. Sayen, M.D. Yellon, and W.H. Dillmann. 1995. Overexpression of the rat inducible $70-\mathrm{kD}$ heat stress protein in a transgenic mouse increases the resistance of the heart to ischemic injury. $J$. Clin. Invest. 95:1446-1456.

71. Plumier, J.C., B.M. Ross, R.W. Currie, C.E. Angelidis, H. Kazlaris, G. Kollias, and G.N. Pagoulatos. 1995. Transgenic mice expressing the human heat shock protein 70 have improved post-ischemic myocardial recovery. J. Clin. Invest. 95:1854-1860.

72. Johnson III, G., P.S. Tsao, and A.M. Lefer. 1991. Cardioprotective effects of authentic nitric oxide in myocardial ishemia with reperfusion. Crit. Care Med. 19:244-252.

73. Siegfried, M.R., C. Carey, X.-L. Ma, and A.M. Lefer. 1992. Beneficial effects of SPM-5185, a cysteine-containing NO donor in myocardial ischemiareperfusion. Am. J. Physiol. 263:H771-H777.

74. Lefer, D.J., K. Nakanishi, W.E. Johnston, and J. Vinten-Johansen. 1993. Antineutrophil and myocardial protecting actions of a novel nitric oxide donor after acute myocardial ischemia and reperfusion in dogs. Circulation. 88:23372350 .

75. Johnson, A.D., P.A. Berberian, M. Tytell, and M.G. Bond. 1995. Differential distribution of $70-\mathrm{kD}$ heat shock protein in atherosclerosis. Its potential role in arterial SMC survival. Arterioscler. Thromb. Vasc. Biol. 15:27-36. 